\title{
Influence of Aggregated Tillage Implements on Fuel Consumption and Wheel Slippage
}

\author{
Robert BENKOVIĆ*, Luka ŠUMANOVAC, Danijel JUG, Irena JUG, Božica JAPUNDŽIĆ-PALENKIĆ, Krunoslav MIROSAVLJEVIĆ, \\ Marina POPIJAČ, Teuta BENKOVIĆ-LAČIĆ
}

\begin{abstract}
Enormous fossil fuel consumption and rising of $\mathrm{CO}_{2}$ exhaust gasses emission has serious influence on greenhouse effect and global climate warming. Nowadays rising fossil fuel prices are leading to an increasing of agricultural products value and awareness of energy efficiency importance. Soil tillage is the largest fuel energy consumer, so there is a need to conduct studies to innovate techniques which can lower fuel consumption. This study evaluates the effects of four different tillage treatments ( $C T$ - conventional, $\mathrm{DH}$ - disc harrowing, $\mathrm{CH}$ - chiselling, $\mathrm{SS}$ - subsoiling) on fuel consumption and wheel slippage. For this research a four-wheel drive tractor was aggregated with reversible plough, discs harrow and with subsoiler as tillage implements. The results indicated that fuel consumption was highest on $\mathrm{CT}$ and the lowest on $\mathrm{DH}$ treatment. $\mathrm{CH}$ treatment had the lowest wheel slippage percentage and average fuel consumption 19,7\% higher than $\mathrm{DH}$ treatment in all three years of the study. Mean wheel slippage at $C T, D H, C H, S S$ treatments was as follows: $17,54 \% ; 21,47 \% ; 8,64 \% ; 23,56 \%$ respectfully. Wheel slippage at $C T, C H$ and $S S$ treatments was related to fuel consumption (as follows: $30,84 \mathrm{lha}^{-1}, 12,92 \mathrm{Iha}^{-1}, 23,1 \mathrm{lha}^{-1}$ ) and all systems were affected by tillage depth.
\end{abstract}

Keywords: conservation tillage; conventional tillage; fuel consumption; reduced tillage; wheel slippage

\section{INTRODUCTION}

Primary task of all branches at agricultural production is to secure enough food for the people population whose number is growing rapidly to almost eight billion. Natural resources such as fertile soil and available energy sources to keep running the necessary agricultural machinery are limited. Interaction of those two elements with current sudden and unstable climate changes complicates the sustainability and safety of agricultural production.

The successful agricultural production depends on input variables such as: soil characteristics, agroclimatic conditions, fertilization, plant protection, variety, applied tillage system and the costs that closely follow the production. Many scientists investigate the impact of different tillage systems on yield [1-3], but there is a need for more intensive research into the impact of tillage systems on reducing high production costs in agriculture.

The development of agricultural mechanization, heavy duty machinery, tillage implements, increased yield and food demands can cause soil's physical degradation recognized in the EU as a crucial concern [4].

Fuel consumption is a variable that varies depending on soil texture, applied tillage system, current soil moisture and crop rotation. Even $55 \%$ to $65 \%$ of total energy in plant production is used to carry out the tillage on heavy clay soils [5]. The unfavorable state of soil moisture, especially during the harvest in the autumn period, affects the poor resistance factor of the wheels of the working machine to rolling $(f=0,08-0,12)$, which increases compaction, shear stress and energy consumption [6]. In plant production technology, soil tillage is one of the main energy-intensive operations. High prices of fuel and the potential possibility of fossil fuels disappearance in the near future directs farmers to implement alternative and more economically sustainable soil tillage technologies. This is reflected in the fact that energy savings are preferred to reduce crops production costs [7].

Author [8] points to the need to increase efficiency and more rational use of energy in the countries of the European Union. Conventional tillage, compared to some kind of unconventional tillage systems, such as conservation, reduced tillage or zero tillage, can save significant amounts of used fuel.

Conservation tillage is a sustainable approach to crop production applicable to all agroecological areas [9], and improves soil quality with optimal yields [10]. Compared to conventional, conservation tillage has a positive impact on soil properties and soil processes [11]. In addition to maintaining favourable moisture in the seed bedding layer, conservation tillage can maintain and even increase yield [12], or reduce yield [13] depending on the area's agroecological conditions. The application of conservation tillage in practice can affect soil physical properties [14], nitrogen content in the soil [15], soil moisture and temperature [16, 17]. Most of agricultural land in Croatia is cultivated conventionally, which includes plug ploughing with additional cultivation, disk-harrowing and some combined implements [18].

By proper aggregation of tractors and attached tillage implements it is possible to increase work efficiency [19] and operating costs of any tillage implement can be reduced by choosing the optimal speed and working depth [20]. Farmers can reduce fuel costs in a large number of ways but primarily through the more economical use of tractors and attached implements. [21] investigated different working operations in a perennial orchard and vineyard and their impact on fuel consumption. The results showed that the highest fuel consumption and the lowest performance was on soil maintenance and on protection belt maintenance machines. Reducing of fuel consumption is one of important factors for sustainable agriculture. It has significant saving's effects and also a direct positive impact on the environment [22].

Soils with a high percentage of clay content (heavy clay soils) are extremely unsuitable for tillage, what is especially expressed at low soil moisture when such soils become very hard. Quite opposite, at high moisture contents heavy clay soils are very plastic and become almost impossible to till, causing the soil stick to the work surface of used tillage implement and the tractor wheels slipping. The optimum moisture of such soils is in narrow range and there is a very short period of time when it is possible to provide tillage without the negative 
consequences on excessive compaction [23]. The aim of this study was to determine the following: the impact of different tractors equipped with tillage implements on fuel consumption, drive wheel slippage, the impact of same tillage implements at different tillage depths on consumption and the impact of conservation tillage related to current soil moisture.

\section{MATHERIAL AND METODS}

A three-year study was conducted in the BrodPosavina County, situated in the eastern part of the Republic of Croatia (Slavonia region). By the Köppen climate classification this region is characterized by medium warm rainy climate with warm summer and without extremely dry periods. The experiment was set up on silty clay soil (pseudogley), classified according to [24], located in village Donja Vrba with the exact coordinates of the test field of $45^{\circ} 10^{\prime} 14^{\prime \prime} \mathrm{N}$ and $18^{\circ} 6^{\prime} 3^{\prime \prime} \mathrm{E}$.

Agricultural soil in the experimental cultivation layer has a very high percentage of coarse silt and silt (82,52\%). Soil samples for determination of mechanical soil structure (Tab. 1) were taken from experimental field in August 2016 by the Thun methodology. Mechanical composition of the soil was determined by a combination of the sifting and sedimentation method by pipetting with sodium pyrophosphate $\left(\mathrm{Na}_{4} \mathrm{P}_{2} \mathrm{O}_{7} \times 10 \mathrm{H}_{2} \mathrm{O}\right)$.

\begin{tabular}{|} 
Table 1 Mechanical soil structure \\
\begin{tabular}{|c|c|c|c|c|c|}
\hline $\begin{array}{c}\text { Coarse sand } \\
(\%)\end{array}$ & $\begin{array}{c}\text { Fine sand } \\
(\%)\end{array}$ & $\begin{array}{c}\text { Coarse silt } \\
(\%)\end{array}$ & $\begin{array}{c}\text { Silt + clay } \\
(\%)\end{array}$ & Silt (\%) & Clay (\%) \\
\hline 5,36 & 8,40 & 37,77 & 48,47 & 44,75 & 3,72 \\
\hline
\end{tabular}
\end{tabular}

Determining of the current soil moisture of each investigated tillage system on the moisture movement was conducted gravimetrically at the same date as tillage treatments for each investigation year. Soil samples were taken at every ten centimetres of depth starting from $10 \mathrm{~cm}$ to $50 \mathrm{~cm}$ depth on all investigated tillage systems. Wet samples were weighed on Ohaus Adventurer pro AV4101 scale and then placed in a Memmert Modell 100-800 dryer. After $24 \mathrm{~h}$ of drying at $105{ }^{\circ} \mathrm{C}$ to constant weight, the samples were weighed again. Current soil moisture (Fig. 5) in weight percentages was calculated by Eq. (1):

$C_{\mathrm{m}}=\frac{M_{\mathrm{ws}}-M_{\mathrm{ds}}}{M_{\mathrm{ds}}} \times 100$

$C_{\mathrm{m}}$ - current soil moisture / \%

$M_{\text {ws }}$ - mass of wet soil

$M_{\mathrm{ds}}-$ mass of dry soil.

After winter wheat, in autumn of 2016 four different soil tillage treatments as the main research factor were applied. As it follows the applied tillage treatments were $C T$ - conventional tillage, $D H$ - disk-harrowing as reduced tillage, $\mathrm{CH}$ - chiselling and $S S$ - subsoiling as conservation tillage. Crop rotation as the second research factor includes crops in the following sequence: soybean (Glycine max L.), maize (Zea mays L.) and winter wheat (Triticum aestivum L.). The two research properties were fuel consumption and wheel slippage during tillage of machinery aggregated with different tillage implements in all investigated treatments.

The experiment was set up as split-plot design (RCBD - randomized complete block design) with four repetitions for each tillage treatment. The size of the basic experimental plot for each individual tillage treatment was $10 \times 92 \mathrm{~m}\left(920 \mathrm{~m}^{2}\right)$. Machinery and aggregated tillage implement used were identical in all the treatments and used as it follows.

A tractor Massey Ferguson 8480 Dyna-VT,4WD, 213 $\mathrm{kW}$, aggregated with a Regent Titan 15 five-furrow reversible plough hydraulic width adjusted (set at $5 \times 40$ $\mathrm{cm}$, grip $=2 \mathrm{~m}$ and a working depth of $35 \mathrm{~cm}$ ) was used for conventional tillage $(C T)$ through all three years of investigation.

The same tractor aggregated with a two-section $R A U$ Rondo XL 44 discs harrow (with 44 discs, diameter of disc $66 \mathrm{~cm}$, a grip of $5 \mathrm{~m}$ and a working depth of $15 \mathrm{~cm}$ ) was used to carry out reduced disc harrow tillage $(D H)$ through all three years of investigation.

For chiselling $(\mathrm{CH})$ conservation tillage through all three years of investigation the same tractor was aggregated with a Pegoraro MEGA DRAG 7 subsoiler with seven working parts (set to a depth of $30 \mathrm{~cm}$ and a grip of $345 \mathrm{~cm})$.

For the subsoiling $(S S)$ tillage through all three years of investigation the tractor is aggregated with same Pegoraro MEGA DRAG 7 subsoiler adjusted on working depth of $50 \mathrm{~cm}$ and a grip of $345 \mathrm{~cm}$.

The mean velocity $\left(\mathrm{ms}^{-1}\right)$ of tractor aggregated with implement during tillage is calculated based on the measured time (s) required to cross a known section in (m) (plot dimensions).

Fuel rate transducers designed to be used in on-board computer at agricultural machines do not depend on viscosity, fuel rate, operation mode, position in space and duration of operation [25]. Same authors in their research determined that variation coefficient and maximum relative error of a fuel portion do not exceed $\pm 0,05$ and $\pm 0,90 \%$ respectively, and the installed transducers have no effect on output characteristics of diesel engines.

Tractor on-board computer "GTA-OPUSA2" was used for volumetric fuel consumption measurement during each pass of aggregated tillage implement per plot $(10 \mathrm{~m}$ wide $\times$ $92 \mathrm{~m}$ long). Number of measurements and passes through each plot depended of tillage implements grip. For every single pass of tractor aggregated with tillage implement board computer measurement started again. Readings of consumption data were recorded and according to them consumption was calculated for each applied tillage system per area $\left(\mathrm{lha}^{-1}\right)$ using the Eq. (2).

$F_{\mathrm{u}}=\frac{V_{\mathrm{m} 1}}{S_{\mathrm{c} 1}} \times 1000$

$F_{\mathrm{u}}$ - fuel used / lha $^{-1}$

$V_{\mathrm{m} 1}$ - fuel volume for one pass of machinery

$S_{\mathrm{cl}}$ - surface covered with one pass of machinery.

The time spent for each tillage pass through plot was measured by the stopwatch of the Sony M4 Aqua android phone. However, for the fuel consumption in relation to covered area, the following parameters were recorded: 
tractor operating speed, wheel slippage and fuel consumption. Slippage is calculated on the base of operator set speed for each tillage system and the actual achieved speed by Eq. (3).

$W_{\mathrm{s}}=\frac{V_{\mathrm{p}}-V_{\mathrm{a}}}{V_{\mathrm{p}}} \times 100$

$W_{\mathrm{s}}$ - wheel slippage / \%

$V_{\mathrm{p}}$ - speed predicted

$V_{\mathrm{a}}$ - speed achieved.

\section{RESULTS AND DISSCUSION}

Tab. 2 shows the results of research on the impact of tillage implements on wheel slippage and fuel consumption. The results were processed by the computer statistical program Statistica v.12. One-way analysis of variance $(p<0,05)$ revealed a statistically significant effect of treatment (soybean $F=152,31$; maize $F=71,51$; winter wheat $F=60,38$ ) on fuel consumption during the work $\left(\mathrm{lha}^{-1}\right.$ ) which averaged 20,60 $\mathrm{lha}^{-1}$ in the first year of research, 19,14 $\mathrm{lha}^{-1}$ in the second year of research and $18,49 \mathrm{lha}^{-1}$ in the third year of research. The highest fuel consumption was measured on $C T$ and the lowest on $D H$ in all three years of the study. These findings are compliant with $[26,27]$. The results they obtained indicated greater fuel consumption at ploughing than at disk harrowing and reduced tillage treatments, respectively.

In the first year of the study (soybean), statistically significant differences were found between $C T$ and $D H$ (24,63 $\left.\mathrm{lha}^{-1}\right), C T$ and $C H\left(24 \mathrm{lha}^{-1}\right), C T$ and SS (14,05 lha $\left.{ }^{1}\right), D H$ and $S S\left(10,58 \mathrm{lha}^{-1}\right) C H$ and $S S\left(9,96 \mathrm{lha}^{-1}\right)$ treatments. These findings are in agreement with [28]. They also noticed that the highest fuel consumption was when attached implements were used for ploughing tillage.

The difference in fuel consumption between $\mathrm{DH}$ and $\mathrm{CH}$ treatments was $0,63 \mathrm{lha}^{-1}$ and was not statistically significant. Statistically significant differences in the second year of the study (maize) were found between the treatments of $C T$ and $D H\left(19,07 \mathrm{lha}^{-1}\right), C T$ and $C H(18,50$ $\left.\mathrm{lha}^{-1}\right), C T$ and $S S\left(6,09 \mathrm{lha}^{-1}\right)$ and between $D H$ and $S S$ $\left(12,98 \mathrm{lha}^{-1}\right)$ and $C H$ and $S S\left(12,41 \mathrm{lha}^{-1}\right)$.

Fuel consumption increases with increase of tillage depth (CH-SS) and soil moisture (Fig. 1, 2016-2018) which is similar to findings of [29].

The difference in fuel consumption between $\mathrm{DH}$ and $\mathrm{CH}$ was $0,57 \mathrm{lha}^{-1}$ and was not statistically significant. In the third year of the study (wheat), statistically significant differences were found between $C T$ and $D H\left(16,42 \mathrm{lha}^{-1}\right)$, $C T$ and $C H\left(11,24 \mathrm{lha}^{-1}\right), C T$ and $S S\left(3,08 \mathrm{lha}^{-1}\right)$ as well as between $D H$ and $C H\left(5,18 \mathrm{lha}^{-1}\right), D H$ and $S S\left(13,34 \mathrm{lha}^{-1}\right)$ and $C H$ and $S S\left(8,16 \mathrm{lha}^{-1}\right)$. During the tillage investigation at winter wheat [30] reported similar highest fuel consumption $\left(25,08 \mathrm{lha}^{-1}\right)$ determined in the mouldboard plough. Authors [31] concluded that reduced tillage depth and equipment weight caused decreasing of fuel consumption during tillage operations. Authors [32] made a comparison of the fuel consumption for tillage and the seeding of winter wheat following three different technologies in Poland. They pointed to the advantages of reduced tillage over conventional tillage system. Their results point to an even greater savings of $22,7 \mathrm{lha}^{-1}$ compared to $C T-D H\left(16,42 \mathrm{lha}^{-1}\right)$.

Table 2 Fuel consumption and wheel slippage during tillage treatments

\begin{tabular}{|c|c|c|c|c|c|c|}
\hline \multirow{2}{*}{ Tillage treatment } & \multicolumn{2}{|c|}{ Soybean (tillage date: 25 . November 2016) } & \multicolumn{2}{|c|}{ Maize (tillage date: 28 . October 2017) } & \multicolumn{2}{|c|}{$\begin{array}{l}\text { Winter wheat (tillage date: } 24 \text {. October } \\
\text { 2018) }\end{array}$} \\
\hline & $\begin{array}{c}\text { Fuel consumption / } \\
\mathrm{lha}^{-1}\end{array}$ & Wheel slippage / \% & $\begin{array}{c}\text { Fuel consumption / } \\
\text { lha }^{-1}\end{array}$ & Wheel slippage / \% & $\begin{array}{c}\text { Fuel consumption / } \\
\mathrm{lha}^{-1}\end{array}$ & Wheel slippage / \% \\
\hline$C T$ & $36,27^{\mathrm{a}}$ & $19,39^{\mathrm{b}}$ & $30,06^{\mathrm{a}}$ & $13,58^{\mathrm{b}}$ & $26,18^{\mathrm{a}}$ & $19,65^{\mathrm{b}}$ \\
\hline $\mathrm{DH}$ & $11,64^{\mathrm{b}}$ & $24,26^{\mathrm{a}}$ & $10,99^{\mathrm{c}}$ & $22,08^{\mathrm{a}}$ & $9,76^{\mathrm{d}}$ & $18,07^{\mathrm{b}}$ \\
\hline $\mathrm{CH}$ & $12,27^{\mathrm{b}}$ & $8,38^{\mathrm{c}}$ & $11,56^{\mathrm{c}}$ & $6,28^{\mathrm{c}}$ & $14,94^{\mathrm{c}}$ & $11,25^{\mathrm{c}}$ \\
\hline$S S$ & $22,22^{\mathrm{c}}$ & $24,02^{\mathrm{a}}$ & $23,97^{\mathrm{b}}$ & $23,71^{\mathrm{a}}$ & $23,10^{\mathrm{b}}$ & $22,96^{\mathrm{a}}$ \\
\hline Mean & 20,60 & 19,01 & 19,14 & 16,41 & 18,49 & 17,98 \\
\hline$F^{*}(p<0,05)$ & $* 152,21$ & $* 82,34$ & $* 71,51$ & $* 23,62$ & $* 60,38$ & $* 41,34$ \\
\hline
\end{tabular}

One-way analysis of variance revealed a statistically significant effect of treatment (soybean $F=82,34$; maize $F$ $=23,62$; wheat $F=41,34)$ on wheel slip (\%), which averaged $19,01 \%$ in the first year, $16,41 \%$ in the second year and $17,98 \%$ in the third year of the study. The lowest wheel slip in all three years of the study was in the $\mathrm{CH}$ treatment. LSD test revealed statistically significant differences between all treatments except between $\mathrm{DH}$ and SS treatments in the first year (difference of 0,24\%) and the second year (difference of $1,63 \%$ ) and $C T$ and $D H$ treatments in the third year (difference of 1,58\%). In the first year of the study, wheel slip on $C T$ treatment was $4,87 \%$ lower compared to $D H, 11,01 \%$ higher compared to $\mathrm{CH}$ treatment and $4,63 \%$ lower compared to $S S$. $D H$ had $15,88 \%$ higher wheel slippage compared to $\mathrm{CH}$ and slippage on $\mathrm{CH}$ was $15,63 \%$ lower compared to $S S$. In terms of first two years of investigation, the results revealed that the wheel slippage was directly related to working width (disc harrowing $=5 \mathrm{~m}$ grip, ploughing $=2$ m grip) of the aggregated tillage implement. The findings between wheel slippage in $\mathrm{CH}$ and $\mathrm{DH}$ are quite opposite to findings of [26]. The possible cause of this is that they used similar working grip tillage implement.

Wheel slippage in the second year of the study in $C T$ treatment was $8,51 \%$ lower compared to $D H$ and $10,13 \%$ lower compared to $S S$, while compared to $C H$, slippage was $7,30 \%$ higher. The difference between $\mathrm{DH}$ and $\mathrm{CH}$ was $15,80 \%$ and was statistically significant as well as the difference between slippage on $\mathrm{CH}$ and $S S$ which was $17,43 \%$. In the third year of the study, wheel slippage in $C T$ treatment was $8,40 \%$ higher compared to $C H$ and $3,31 \%$ lower compared to $S S$. Slippage on $D H$ was $6,82 \%$ higher compared to $\mathrm{CH}$ and $4,89 \%$ lower compared to $S S$. Slip on $S S$ treatment was $11,71 \%$ higher than $C H$. In all three years of the study, the wheel slippage on the $S S$ treatment was significantly higher than on the $\mathrm{CH}$, which indicates the fact that the working depth affects the slippage. [29, 33] determined that wheel slippage and fuel 
consumption increased almost quadratically with working depth.

This paper presents a regression analysis of the impact of tractor wheel slip on fuel consumption in four tillage variants: conventional tillage $(C T)$, disc harrowing $(D H)$, chiselling $(C T)$ and subsoiling $(S S)$. The selection of the regression equation between the five possibilities (linear, quadratic, potential, logarithmic and exponential) is based on the selection with respect to the highest value of the correlation coefficient between the observed features. The intensity or strength of the bond between the two features is defined by the correlation coefficient $(R)$ and is ranked according to the Roemer-Orphal scale. The coefficient of determination $\left(R^{2}\right)$ represents the interpretation of the influence of the independent variable on the dependent variable and is usually expressed in \%. The remainder, explained by the influence of some other unexplored factors, is expressed by the alienation coefficient $\left(1-R^{2}\right)$, also in $\%$.

The results of the regression analysis show the existence of a linear dependence between tractor wheel slip and the average fuel consumption for all three agricultural crops in conventional tillage $(C T)$ in the studied period (Fig. 1). For soybean, this dependence can be presented by a linear regression equation: $y=1,4669 x+8,216$ with a correlation coefficient $R=0,987$, while at the same time for maize this dependence is defined by the equation: $y=$ $0,6697 x+20,962$ also with an extremely high correlation coefficient $R=0,991$. For the third agricultural crop, ie for winter wheat, the dependence was defined by a linear equation of the following form: $y=1,4273 x-1,8694$ with a correlation coefficient $R=0,994$.

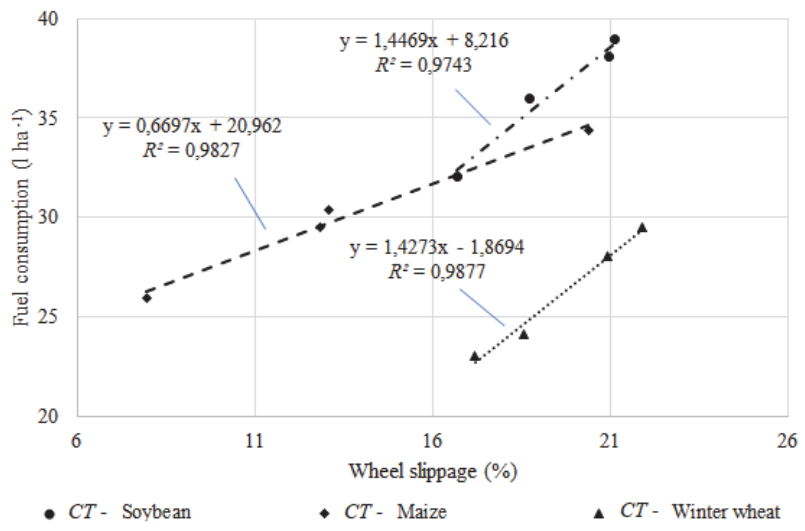

Figure 1 Influence of tractor wheel slip rate on fuel consumption - CT treatment

In order to determine the significance of the correlation coefficient, (i.e. whether it differs significantly from zero, regardless of the sign), the significance of the correlation coefficient for the investigated characteristics was tested at the significance level of $5 \%$ and $1 \%$, using standard statistical methods. After testing the significance of the correlation coefficient at the level of $5 \%$ and $1 \%$, it can be concluded that the tabular value of $t$ with two degrees of freedom is $t_{5}=4,31$, and $t_{1}=9,09$, and the calculated value for soybean is 8,73 . The calculated $t$ is significantly higher at the significance threshold level of $5 \%$ than the tabular $t_{5}$ indicating a statistically significant correlation, while at the significance threshold level of $1 \%$ the correlation is not statistically significant. For maize, the calculated value of $t$ is 10,65 , which indicates the statistical significance of the correlation for both levels of $5 \%$ and $1 \%$, since the calculated value of $t$ is higher than the table values of $t_{5}=$ 4,31 , and $t_{1}=9,09$. Finally, testing was performed for winter wheat in the third year of the study, and the calculated $t$ is 12,64 , which is significantly higher than the tabular values of $t_{5}=4,31$, and $t_{1}=9,09$, which suggests a conclusion on the statistical significance of the correlation.

In the disk-harrowing tillage $(D H)$ variant (Fig. 2), the dependence between the investigated factors for the soybean is exponential shape and it is expressed by the equation $y=3,3307 \cdot \mathrm{e}^{0,0516 x}$ with the corresponding correlation coefficient $R=0,868$. In maize production, the dependence between slippage and fuel consumption is logarithmic, expressed by the equation $y=6,5173 \cdot \ln x-$ 9,1325 with a correlation coefficient $R=0,9$, while in winter wheat production the dependence of the exponential form $y=3,5508 \cdot \mathrm{e}^{0,0559 x}$ with identical correlation coefficient $R=0,9$.

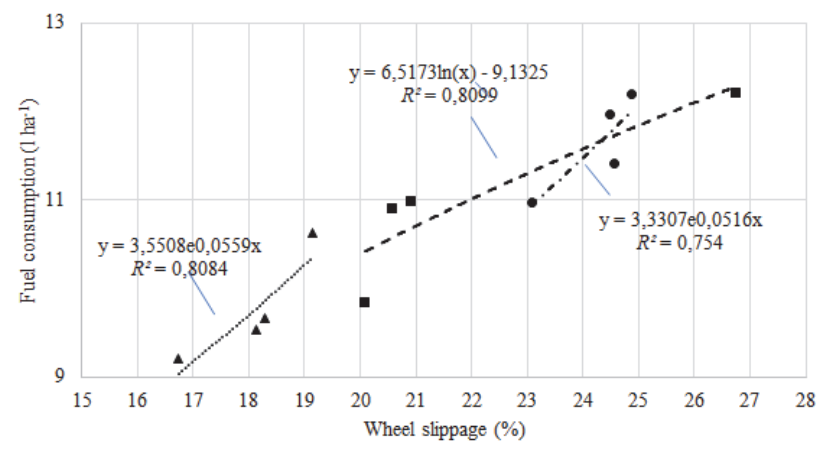

- $D H$ - Soyabean $\Delta D H$ - Winter wheat - $D H$ - Maize Figure 2 Influence of tractor wheel slip rate on fuel consumption - $D H$ treatment

The performed testing of the significance of the correlation coefficient for the variant of disk-harrowing tillage in the first year of research, ie for soybean, indicates that the tabular values $t_{5}=4,31$, and $t_{1}=9,09$ are significantly higher than the calculated $t$ value of 2,47 , which indicates the absence of statistical significance of the correlation. In the second and third year of the research, ie in maize and winter wheat, the calculated $t$ is 2,91 and 2,9, which also indicates the absence of statistical significance for both crops.

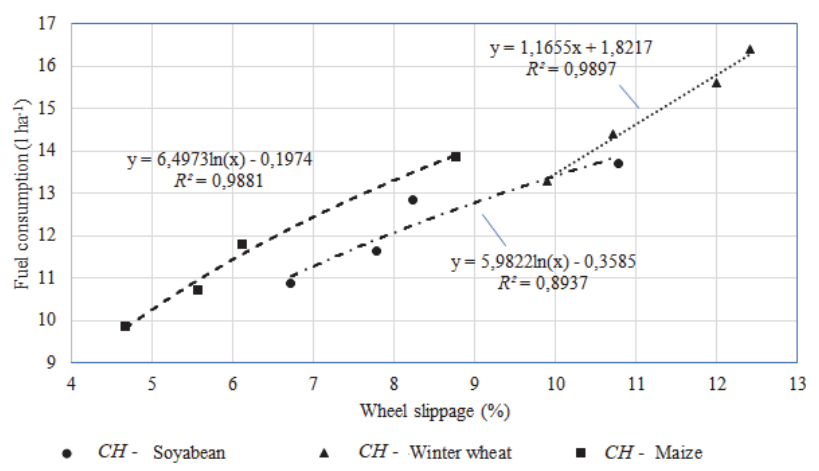

Figure 3 Influence of tractor wheel slip rate on fuel consumption - $\mathrm{CH}$ treatment

In the third variant of tillage, chiselling $(\mathrm{CH})$ (Fig. 3), the dependence for soybean is shown by the logarithmic equation of the following form $y=5,9822 \cdot \ln x-0,3585$ with a correlation coefficient $R=0,945$. In maize production, the dependence between the investigated factors is logarithmically expressed by the equation $y=$ 
$6,4973 \cdot \ln x-0,1974$, while the correlation coefficient $R=$ 0,994 is extremely high. In the production of winter wheat, the relationship between the degree of wheel slip and fuel consumption of the power unit is linear and is shown by the equation of the direction $y=1,1655 x+1,8217$ with a correlation coefficient $R=0,994$.

Finally, the significance of the correlation coefficient was determined at the significance level of $5 \%$ and $1 \%$ for the variant of chiselling. The tabular value of $t$ with two degrees of freedom is $t_{5}=4,31, t_{1}=9,09$, and the calculated value of $t$ for soybean is 4,01 . Since the calculated $t$ is smaller than the tabular $t_{5}$ and $t_{1}$ it can be concluded that the correlation is not statistically significant. In maize production, the calculated $t$ is 12,91 , which indicates the statistical significance of the correlation, while for winter wheat, the calculated $t$ has a value of 14 , which is significantly higher than the tabular values, which indicates a high statistical significance of the correlation.

In the last variant of tillage, ie in subsoiling $(S S)$ (Fig. 4) for soybean, maize and winter wheat, the dependence is determined by logarithmic equations. For soybean, the equation has the following form $y=22,531 \cdot \ln x-49,359$, with a correlation coefficient $R=0,94$. For maize the equation is $y=25,11 \cdot \ln x-55,543$ with a regression coefficient $R=0,953$ and finally for winter wheat the regression equation has the following form $y=21,009 \cdot \ln x$ $-42,473$ with an extremely high regression coefficient $R=$ 0,978 .

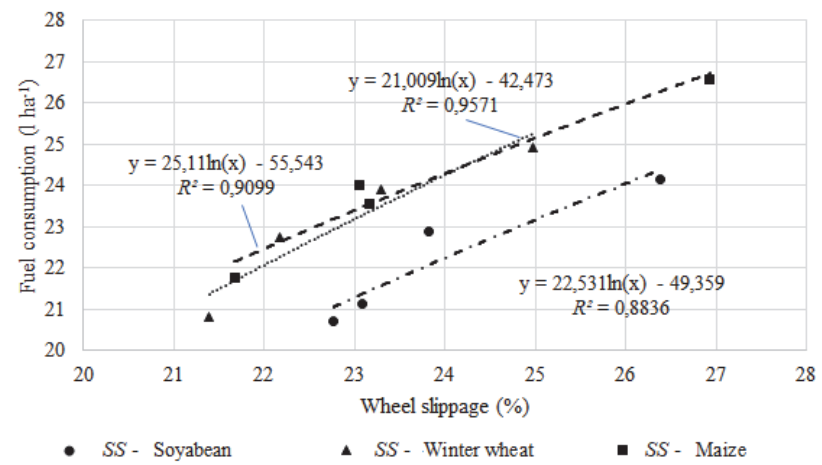

Figure 4 Influence of tractor wheel slip rate on fuel consumption - SS treatment

After testing the significance of the correlation coefficient at the level of $5 \%$ and $1 \%$, in the variant of subsoiling, the calculated $t$ for soybean is 3,88, which indicates that the correlation is not statistically significant, while the calculated $t$ value for maize is 4,5 , which indicates statistical significance for the significance level of $5 \%$, while for the significance level of $1 \%$ the correlation is statistically insignificant. For winter wheat, the calculated $t$ is 6,65 , which means that the correlation is significant for the threshold, i.e. the significance level of $5 \%$, while for the significance threshold of $1 \%$ the correlation is statistically insignificant. The tabular values of $t$ with two degrees of freedom are $t_{5}=4,31, t_{1}=9,09$ as in the previous variants of tillage.

The current soil moisture (Fig. 5) at the depth of $10 \mathrm{~cm}$ to $30 \mathrm{~cm}$ in the first year of the study was $13,25 \%$ higher than in the second year and $33,66 \%$ higher than in the third year. At the depths of $10 \mathrm{~cm}$ to $50 \mathrm{~cm}$, the current soil moisture was again the highest in the first year of study with $9,01 \%$ compared to the second year and $27,93 \%$ compared to the third year.

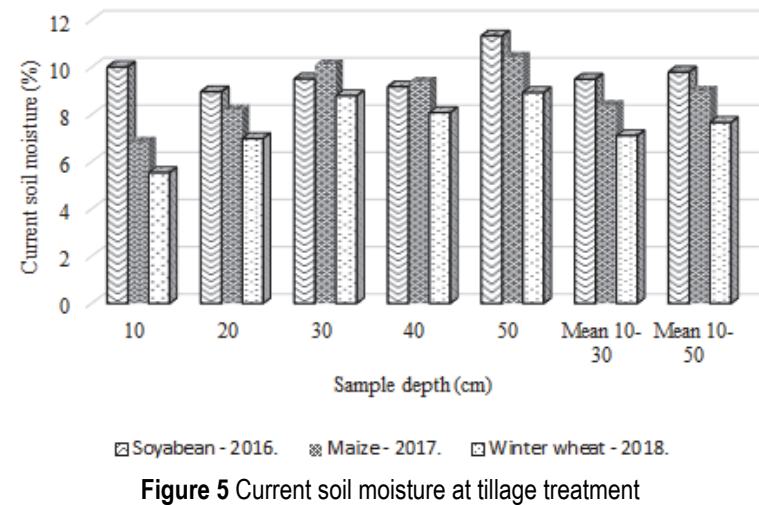

The current soil moisture at the investigated treatments and the tillage depths take effect at fuel consumption. Mean fuel consumption was the highest at the first year $(20,60$ $\left.1 \mathrm{l}^{-1}\right)$ and the lowest in the third year of this study $(18,49$ $\left(\mathrm{lha}^{-1}\right)$. [34] had similar results. Fuel consumption differences (winter wheat, barley, maize, soybean) were slight and mainly influenced by different soil moisture content at the time of tillage operations. They also noticed that the greatest fuel consumption was recorded at soils with silt clay texture closely similar to one in this study. There is a profound effect of moisture content on wheel slippage. These results are in similarity with those of [35]. Their study also found that increase in fuel consumption is dependent variable, because its consumption depends upon different factors.

\section{CONCLUSION}

The results of this study of different tillage treatments in a region with silty clay soil (pseudogley) indicated significant reductions in fuel consumption and wheel slippage losses. Fuel consumption of tillage with aggregated implement is greatly affected by the working depth. The wheel slippage during tillage processes becomes an important factor for analysis of fuel consumption. Increasing working depth or implements grip caused increase of wheel slippage. The result is a highest fuel consumption ( $\mathrm{lha}^{-1}$ ) at $C T$ and lowest at $D H$ treatment in all three years of research. $\mathrm{CH}$ treatment had the lowest wheel slippage percentage and average fuel consumption $19,7 \%$ higher than $D H$ in all three years, so it can be recommended as acceptable tillage system. In this research $S S$ had very high rates of fuel consumption and wheel slippage so it can be recommended only as conservation tillage for breaking of a compacted impermeable deeper soil layer and improving soil water management.

Fuel consumption and wheel slippage were related to working depth, tillage implement grip and current soil moister content. Reduced tillage $\mathrm{DH}$ and conservation tillage $\mathrm{CH}$ were found more economically usable compared to $C T$ applications within this scope.

This study's realistic conditions, field measurements and results calculated from the collected data will be useful for determination of economic efficiency of different soil tillage systems for agricultural producers. It also points to possible ways of making more significant contributions to 
the sustainability of agriculture in terms of use of conservation or reduced tillage in soil protection and fossil fuel savings.

\section{REFERENCES}

[1] Jug, D., Stipešević, B., Jug, I., Stošić, M., \& Kopas, G. (2006). Yield of maize (Zea mays L.) on different soil tillage variants. Poljoprivreda, 12(2), 5-10. https://doi.org/10.18047/poljo.

[2] Stosic, M., Brozovic, B., Vinkovic, T., Tkalec Kojic, M., Šumanovac, L., \& Tadic, V. (2020). Long-term tillage and nitrogen fertilization for soybean on gley soil, Nardifundulea. Romanian agricultural research, 37, 151160.

[3] Acar, M., Çelik, I., \& Günal, H. (2017). Effects of long-term tillage systems on soil water content and wheat yield under Mediterranean conditions. Journal of New Theory, 17, 98108.

[4] Virto, I., Imaz, M. J., Fernández-Ugalde, O., GartziaBengoetxea, N., Enrique, A., \& Bescansa, P. (2015). Soil degradation and soil quality in Western Europe: current situation and future perspectives. Sustainability, 7(1), 313365. https://doi.org/10.3390/su7010313

[5] Pellizzi, G., Cavalchini, A. G., \& Lazzari, M. (1988). Energy savings in agricultural machinery and mechanization. London-New York, NY: Elsevier Applied Science. https://doi.org/10.1017/S0021859600084756

[6] Šumanovac, L., Sebastijanović, S., \& Kiš, D. (2011). Transport u poljoprivredi. Osijek, University textbook.

[7] Bayhan, Y., Kayisoglu, B., Gonulol, E., Yalcin, H., \& Sungur, N. (2006). Possibilities of direct drilling and reduced tillage in second crop silage corn. Soil and Tillage Research, 88(1-2), 1-8. https://doi.org/10.1016/j.still.2005.04.012

[8] Gorcianska, J. (2011). Fuel savings in agriculture - new priorities of the European Union. Journal of Research and Applications in Agriculture Engineering, 56(2), 54-57.

[9] Ceglar, A., Croitoru, A. E., Cuxart, J., Djurdjevic, V., Güttler, I., Ivančan-Picek, B., Jug, D., Lakatos, M., \& Weidinger, T. (2018). PannEx: the pannonian basin experiment. Climate Service, (11), 78-85. https://doi.org/10.1016/j.cliser.2018.05.002

[10] Jug, D., Jug, I., Brozović, B., Vukadinović, V., Stipešević, B., \& Đurđević, B. (2018). The role of conservation agriculture in mitigation and adaptation to climate change. Poljoprivreda, 24(1), 35-44. https://doi.org/10.18047/poljo.24.1.5

[11] Palm, C., Blanco-Canqui, H., DeClerck, F., Gatere, L., \& Grace, P. (2014). Conservation agriculture and ecosystem services: an overview. Agriculture, Ecosystems \& Environment, 187, 87-105. https://doi.org/10.1016/j.agee.2013.10.010

[12] Nyakatawa, E. Z., Reddy, K. C., \& Mays, D. A. (2000). Tillage, cover cropping, and poultry litter effects on cotton. II Growth and yield parameters. Agronomy Journal, 92, 1000-1007. https://doi.org/10.2134/agronj2000.9251000x

[13] Schwab, E. B., Reeves, D. W., Burmester, C. H., Raper, \& R. L., (2002). Conservation tillage systems for cotton in the Tennessee Valley. Soil Science Society of America Journal, 66, 569-577. https://doi.org/10.2136/sssaj2002.5690

[14] Czyż, E. A. \& Dexter, A. R. (2008). Soil physical properties under winter wheat grown with different tillage systems at selected locations. International Agrophysics, 22, 191-200.

[15] Torbert, H. A., Potter, K. N., \& Morrison, J. E. (2001). Tillage system, fertilizer nitrogen rate, and timing effect on corn yields in the Texas Blackland Prairie. Agronomy Journal, 93(5), 1119-1124. https://doi.org/10.2134/agronj2001.9351119x
[16] Nadelhoffer, K. J., Gibblim, A. E., Shaver, G. R., \& Laundre, J. A. (1991). Effect of temperature and substrate quality on element mineralization, in six arctic soils. Ecology, 72, 242253. https://doi.org/10.2307/1938918

[17] Torbert, H. A. \& Wood, C. W. (1992). Effects of soil compaction and water -filled pore space on soil microbial activity and N losses. Communications in Soil Science and Plant Analysis Soil, 23, 1321-1331. https://doi.org/10.1080/00103629209368668

[18] Košutić, S., Filipović, D., \& Gospodarić, Z. (2001). Maize and winter wheat production with different soil tillage systems on silty clay. Agricultural and Food Science in Finland, 10, 81-90. https://doi.org/10.23986/afsci.5686

[19] Filipović, D., Košutić, S., \& Gospodarić, Z. (2005). Energy requirement in conventional tillage of silty clay soil in west slavonia, Agronomski glasnik, 67(5), 383-392. https://doi.org/10.33128/ag

[20] Kheiralla, A. F., Yahya, A., Zohadie, M., \& Ishak, W. (2004). Modelling of power and energy requirements for tillage implements operating in Serdang sandy clay clay, Malaysia. Soil and Tillage Research, 78, 21-34. https://doi.org/10.1016/j.still.2003.12.011

[21] Sito, S., Bilandžija, N., Šket, B., Hrvojčec, H., Kraljević, A., \& Ivandija, M. (2016). Fuel consumption and machinery performance in permanent crops production. Proceedings of the $51^{\text {th }}$ Croatian and $25^{\text {th }}$ International Symposium of Agriculture, Opatija, 512-516.

[22] Poje, T., Jejčić, V., \& Sito, S. (2017). Lower fuel consumption - one of the conditions for sustainable agriculture. Glasnik zaštite bilja, 4, 16-23. https://doi.org/10.31727/gzb.40.4.1

[23] Weise, G. \& Bourarach, E. H. (1999). Tillage Machinery. Plant Production Engineering, 3. ASAE, St. Joseph, Michigan, USA, 184-217. http://doi:10.13031/2013.36343

[24] FAO, 1990. Soil Map of the World. FAO, Rome. Retrieved from https://www.isric.org/sites/default/files/ISRIC TechPap20.pdf

[25] Boikov, V., Uspenskiy, A., \& Krasnevski, L. (1998). Diaphragm Chamber Fuel Flow Transducers for On-Bord Computersof Mobile Agricultural Machines. International Off-Highway and Powerplant Congress and Exposition Milwaukee, 1-6. https://doi.org/10.4271/982048.

[26] Leghari, N., Oad, V. K., Shaikh, A. A., \& Soomro, A. A. (2016). Analysis of different tillage implements with respect to reduced fuel consumption, tractor operating speed and its wheel slippage. Sindh University Research Journal (Science Series), 48(1), 37-40.

[27] Šarauskis, E., Buragiene, S., Romaneckas, K., Sakalauskas, A. Jasinskas, A., Vaiciukevicius, E., \& Karayel, D. (2012). Working time, fuel consumption and economic analysis of different tillage and sowing systems in Lithuania. Engineering for Rural Development, 11, 52-59.

[28] Stajnko, D., Lakota, M., Vučajnk, F., \& Bernik R. (2009). Effect of different tillage systems on fuel savings and reduction of $\mathrm{CO} 2$ emissions in production of silage corn in eastern Slovenia. Polish Journal of Environmental studies, 18(4), 711-716. https://doi.org/10.2507/daaam.scibook.2009.56

[29] Moitzi, G., Wagentristl, H., Refenner, K., Weingartmann, H., Piringer, G., Boxberger, J., \& Gronauer, A. (2014). Effects of working depth and wheel slip on fuel consumption of selected tillage implements. Agriculture Engineering International CIGR journal, 6(1), 182-190.

[30] Gozubuyuk, Z., Sahin, U., \& Celik, A. (2020). Operational and yield performances and fuel-related $\mathrm{CO}_{2}$ emissions under different tillage-sowing practices in a rainfed crop rotation, International Journal of Environmental Science and Technology, 17, 4563-4576. https://doi.org/10.1007/s13762-020-02804-y

[31] Mamkagh, A. M. (2018). Effect of tillage speed, depth, ballast weight and tire inflation pressure on the fuel 
consumption of the agricultural tractor, a review. Journal of Engineering Research and Reports, 3, 1-7. https://doi.org/10.9734/jerr/2018/v3i216871

[32] Jaskulska, I.. \& Jaskulski, D. (2020.). Strip-Till One-Pass Technology in Central and Eastern Europe, A MZURI ProTil Hybrid Machine Case Study, Agronomy, 10(7), 925. https://doi.org/10.3390/agronomy10070925

[33] Moitzi, G., Weingartmann H., Wagentristl H., Refenner K., \& Boxberger J. (2008). Fuel consumption at subsoiling, Land Technik, 63(1), 18-19.

[34] Filipović, D., Kosutić, S., Gospodarić, Z., Zimmer, R., \& Banaj, Đ. (2006). The possibilities of fuel savings and the reduction of $\mathrm{CO} 2$ emissions in the soil tillage in Croatia, Agriculture, Ecosystems and Environment, 115, 290-294. https://doi.org/10.1016/j.agee.2005.12.013

[35] Namdari, M., Rafiee, S., \& Jafari, A. (2011). Using the FMEA method to optimize fuel consumption in tillage by mouldboard plow, International Journal of Applied Engineering Research, 1(4), 734-742.

\section{Contact information:}

Robert BENKOVIĆ, PhD student

(Corresponding author)

University of Slavonski Brod, BIODpt,

Trg Ivane Brlić Mažuranić 2, 35000 Slavonski Brod, Croatia

E-mail: rbenkovic@unisb.hr

Luka ŠUMANOVAC, PhD, Full Professor

Faculty of Agribiotechnical Sciences Osijek,

Vladimira Preloga 1, HR-31000, Osijek, Croatia

E-mail: Isumanov@fazos.hr

Danijel JUG, PhD, Full Professor

Faculty of Agribiotechnical Sciences Osijek,

Vladimira Preloga 1, HR-31000, Osijek, Croatia

E-mail: jdanijel@fazos.hr

Irena JUG, PhD, Full profesor

Faculty of Agribiotechnical Sciences Osijek,

Vladimira Preloga 1, HR-31000, Osijek, Croatia

E-mail: ijug@fazos.hr

Božica JAPUNDŽIĆ-PALENKIĆ, PhD

University of Slavonski Brod, BIODpt,

Trg Ivane Brlić Mažuranić 2, 35000 Slavonski Brod, Croatia

E-mail: bjpalenkic@unisb.hr

Krunoslav MIROSAVLJEVIĆ, PhD, Associate Professor

University of Slavonski Brod, BIODpt,

Trg Ivane Brlić Mažuranić 2, 35000 Slavonski Brod, Croatia

E-mail: kmirosavljevic@unisb.hr

Marina POPIJAČ, PhD

Public Institution Nature Park Medvednica,

Bliznec 70, 10000 Zagreb, Croatia

E-mail: marina.popijac@pp-medvednica.hr

Teuta BENKOVIĆ-LAČIĆ, PhD, Assistant Professor

University of Slavonski Brod, BIODpt,

Trg Ivane Brlić Mažuranić 2, 35000 Slavonski Brod, Croatia

E-mail: tblacic@unisb.hr 